Yale Agrarian Studies Series

JAMES C. SCOTT, SERIES EDITOR 
The Agrarian Studies Series at Yale University Press seeks to publish outstanding and original interdisciplinary work on agriculture and rural society - for any period, in any location. Works of daring that question existing paradigms and fill abstract categories with the lived experience of rural people are especially encouraged. -James C. Scott, Series Editor

James C. Scott, Seeing Like a State: How Certain Schemes to Improve the Human Condition Have Failed

Steve Striffler, Chicken: The Dangerous Transformation of America's Favorite Food

James C. Scott, The Art of Not Being Governed: An Anarchist History of $U_{p-}$ land Southeast Asia

Timothy Pachirat, Every Twelve Seconds: Industrialized Slaughter and the Politics of Sight

Edward Dallam Melillo, Strangers on Familiar Soil: Rediscovering the ChileCalifornia Connection

Kathryn M. de Luna, Collecting Food, Cultivating People: Subsistence and Society in Central Africa through the Seventeenth Century

James C. Scott, Against the Grain: A Deep History of the First Civilizations

Loka Ashwood, For-Profit Democracy: Why the Government Is Losing the Trust of Rural America

Jonah Steinberg, A Garland of Bones: Child Runaways in India

Hannah Holleman, Dust Bowls of Empire: Imperialism, Environmental Politics, and the Injustice of "Green" Capitalism
Johnhenry Gonzalez, Maroon Nation: A History of Revolutionary Haiti

Christian C. Lentz, Contested Territory: Điện Biên Phu and the Making of Northwest Vietnam

Dan Allosso, Peppermint Kings: A Rural American History

Jamie Kreiner, Legions of Pigs in the Early Medieval West

Christian Lund, Nine-Tenths of the Law: Enduring Dispossession in Indonesia

Shaila Seshia Galvin, Becoming Organic: Nature and Agriculture in the Indian Himalaya

Michael Dove, Bitter Shade: The Ecological Challenge of Human Consciousness

Japhy Wilson, Reality of Dreams: PostNeoliberal Utopias in the Ecuadorian Amazon

Aniket Aga, Genetically Modified Democracy: Transgenic Crops in Contemporary India

Ruth Mostern, The Yellow River: A Natural and Unnatural History

Brian Lander, The King's Harvest: A Political Ecology of China from the First Farmers to the First Empire

For a complete list of titles in the Yale Agrarian Studies Series, visit yalebooks.com/ agrarian. 


\title{
REALITY OF DREAMS
}

\author{
POST-NEOLIBERAL UTOPIAS \\ IN THE ECUADORIAN AMAZON
}

JAPHY WILSON

\section{Yale}

UNIVERSITY PRESS

New Haven and London 
Copyright (C) 202I by Yale University.

All rights reserved.

This book may not be reproduced, in whole or in part, including illustrations, in any form (beyond that copying permitted by Sections IO7 and 108 of the U.S. Copyright Law and except by reviewers for the public press), without written permission from the publishers.

Yale University Press books may be purchased in quantity for educational, business, or promotional use. For information, please e-mail sales.press@ yale.edu (U.S. office) or sales@yaleup.co.uk (U.K. office).

Set in Gotham \& Adobe Garamond type by IDS Infotech Ltd., Chandigarh, India.

Printed in the United States of America.

Library of Congress Control Number: 2020952830

ISBN 978-0-300-25342-9 (paper : alk. paper)

A catalogue record for this book is available from the British Library.

This paper meets the requirements of ANSI/NISO Z39.48-I992 (Permanence of Paper).

I0 98765432 I 
For Molly 
This page intentionally left blank 
It seems to me I am trying to tell you a dream-making a vain attempt, because no relation of a dream can convey the dream-sensation, that commingling of absurdity, surprise, and bewilderment ... that notion of being captured by the incredible which is of the very essence of dreams.

Marlow, in Joseph Conrad's Heart of Darkness 
This page intentionally left blank 